trees of the forest, and is capable of producing in a good season as much as from Io to I $5 \mathrm{lbs}$. of rubber per tree. For the purpose of extracting the rubber, a deep vertical cut is made through the bark, and several oblique cuts on each side running into the main channel, at the base of which a vessel is placed to receive the exuding milk, which is coagulated by allowing a quantity to stand for some days in a cavity made in the trunk of a tree, so hat the watery portion evaporates or soaks into the wood, leaving the solid portion behind, which is kneaded and pressed together into a solid mass, or the milk is placed in a vessel and boiled, the rubber beginning to coagulate almost immediately heat is applied. The whole history of this interesting discovery and development is given in the Kew Bulletin for 1895, p. 24I, and 1896 , p. 76 , from which we learn that in January I895, which practically marks the beginning of the industry, the exports were $2 \mathrm{I}, 13 \mathrm{I} l \mathrm{lbs}$, , valued at $\mathrm{I}_{2} \mathrm{I} 4 l$., and at the end of December of the same year this had increased to such an extent as to show a total for the twelve months of $5,069,504$ lbs., of the value of $269,892 l$. I $3 s$. Iod.

As the Bulletin remarks, "The history of this new rubber industry in Lagos is full of interest, and illustrates the wonderfully rich resources of the vast forests of West Africa. It shows also very clearly how largely these resources can be developed by judicious and intelligent action on the part of the Government."

Besides the important sources of rubbers already mentioned, there are still others belonging to the same natural order Apocynaceæ, natives of the Far East, which may be briefly referred to species of Willughbeia and Leuconotis. Alstonia plumosa yields a rubber in $\mathrm{Fiji}$, whilst Forsteronia floribund $a$ and $F$. gracilis yield rubbers in small quantities in Jamaica and Demerara respectively, though not in sufficient quantities to be of any commercial importance.

From the foregoing list of plants, it will be seen how generally distributed the elastic juices are in Apocynaceous plants.

Space will scarcely allow us even to mention the allied substance gutta-percha, the history of the introduction, development, and threatened failure of supply of which is fraught with so much interest and warning : how that in I 842 the substance was first discovered in Singapore, and the trees cut down in such large numbers to supply the European demand, that in five years after only a few trees existed in Singapore, and a similar fate attending the trees which were afterwards found in Penang, are facts that are well known as applying to Dichopsis gutto, a sapotaceous tree, upon which the reputation of guttapercha was at first founded, and from which the bulk of the commercial supplies have continued to be drawn, though it is more than probable that a similar substance is yielded in the East by allied trees, the botany of which, however, is but imperfectly known.

A substance very like gutta-percha is furnished by Mimusops globosa, a large forest tree, growing to a height of from 60 to 70 or even roo feet, in Trinidad, Jamaica, Venezuela, and British Guiana. It belongs to the Sapotacea, and the solidified milk, or gutta, was first brought to this country in 1859 . Its use with us has fluctuated very much, and it cannot be looked upon as a perfect substitute for true gutta-percha.

The interest at the present time is much greater towards the rubber supplies than those of gutta, and this is borne out by a few facts referring to the probable demand, in the very near future, that have appeared in a recent number of our contemporary, Commerce, among them being a statement that the estimated outturn of cycles in Great Britain and the United States during the present year will amount to $1,750,000$; besides this, there is the probable development of motor carriages, and the extended application of rubber for the tyres of ordinary vehicles. So that there is every probability that the interest in rubber-yielding plants will go on increasing.

Museum, Royal Gardens, Kew.

\section{THE RESOURCES AND THE NEEDS OF} CAMBRIDGE UNIVERSITY.

H IS GRACE THE DUKE OF DEVONSHIRE, K.G., Chancellor of the University of Cambridge, has requested us to give publicity to a statement as to its innancial position and requirements, which has been drawn up for him by an influential Committee of residents, and whose authority he states to be unquestionable. Its purpose is to make known to the public the true state of the University's finances in relation to its increased duties, in the hope that means may be found for raising its endowments to the level of its present requirements

The statement seeks to remove the impression that the University is a wealthy body. The fall in agricultural values has so seriously crippled it and its constituent Colleges, that this impression is no longer justified; and a point has been reached at which, without new endowments, complete efficiency and necessary expansion are gravely impeded. Benefactions for the establishment of special prizes and scholarships have not been wanting; but the flow of contributions for general academic purposes has for years practically ceased, though it is such gifts that are most needed, and at present most likely to be widely useful.

It appears that while the Colleges undertake much of the teaching for the degree examinations in mathematics and classics, all the higher branches, and the entire round of the natural and physical sciences, are provided for by the University, which maintains the library, the observatory, the botanic garden, eight museums, and eight laboratories. The University staff consists of about I 20 professors, readers, and lecturers, whose stipends are paid partly by the common fund, partly by their emoluments as Fellows and Lecturers of Colleges. A Professor's stipend of $700 l$. or $800 l$. is diminished by $200 l$. if he holds a Fellowship ; but in nearly all the Colleges the dividend is less than this sum, and the Professor, therefore, does not receive his full nominal stipend. By the statutes there should be twenty Readerships at $400 l$. each: the University has been able to establish six only, and these, in general, at stipends of about $100 l$. to I $50 l$. The University Lecturers are usually selected from the College staffs, and receive, as a rule, stipends of $50 l$. a year.

In consequence of the conditions established in I88I, four-fifths of the Fellowships are now held by resident graduates. The maximum dividend is fixed at $250 l$., but in fifteen out of seventeen Colleges this sum is not reached, and in some the dividend does not exceed onethird of the maximum.

The revenue for I 896 consisted of about 40,000l. derived from fees; about 16,500l. contributed by the Colleges as a tax on their revenues and tuition-fees; and about $6000 l$. obtained from the University endowments (tithes, rents, \&c.). Of this sum, over 33,000 . was paid in stipends; over $22,000 l$. for the maintenance of libraries, museums, laboratories, \&c. ; some $2200 l$. in repayment of a loan for buildings; and $5000 l$. in part payment of necessary sites for new buildings adjoining the present museums.

From fees it is not easy to see how more can be derived without diminishing the number of students and graduates; the endowments are insignificant, and steadily decreasing in value; and the College contribution has already, in view of the financial difficulties of these corporations, been more than once reduced. When the tax reaches its maximum in 1902 , the most it can yield, in addition to its present amount, is probably about $2000 l$.

On the other hand, greater expenditure is called for in

$$
\text { xO. } 14.35 \text {. VOL. } 55 \text { ] }
$$


various necessary directions. The museums and latoratories have been practically created within the present generation, but already many of them require considerable extension and better equipment. Important branches of study are rightly claiming recognition, but their demands cannot be met without heavy capital outlay. New sites have been secured, but the money to build on them is not forthcoming. The University library must be extended; the school of law is without a building; the lecture-rooms for the literary and philosophical subjects are wholly inadequate; there are neither central offices for University business, nor suitable rooms for University examinations; lastly, the laboratories for botany, zoology, and pathology must be rebuilt; the departments of physiology, physics, and engineering need speedy enlargement, and the school of medicine (including pharmacology) is practically beyond repair, and must be reconstructed on another site.

It is pointed out that while the total divisible income of the Colleges has fallen by 34 per cent. in the last fifteen years, the number of students has increased to 3000. Much personal devotion and sacrifice on the part of the teachers, much self-denial on the part of the Colleges which have not reduced their scholarships, and ther encouragements for the poorer students, and much enthusiasm for the progress of science and learning on the part of all, must have gone to produce a result so creditable to the University. It appears to us that a fair case has been made out for its substantial re-endowment in respect of many of its departments; and, though no appeal for subscriptions is made, the facts related in the Chancellor's statement may well be pondered by those who are in a position to display a wise liberality in the cause of education, learning, and research.

\section{NOTES}

AT a meeting held on April 13, the Academy of Natural Sciences of Philadelphia conferred the Hayden Memorial Award for 1897 , consisting of a bronze medal and the interest of the special endowment fund, on Prof. A. Karpinski, the Chief of the Geological Survey of Russia, in recognition of the value of his contributions to geological and palæontological science.

THE Budget Commission of the French Government has decided that the sum of four thousand pounds be voted for the Pasteur Institute at Rhia-Trang, to encourage Dr. Yersin's researches on the plague serum. The Chamber of Deputies is asked to adopt this decision.

THE British Medical Journal says there is a Bill before the New York State Legislature which provides for the establishment of a laboratory for the preparation of evidence for use in future trials for murder conducted by the State. In a recent case $1450 \%$. was paid to medical witnesses for giving expert evidence. The object of the new Bill is to save this expense.

Sir EdWARD NEwTon, K.C. M.G., died at Lowestoft on April 25, in the sixty-fifth year of his age. The youngest son of the late Wm. Newton, of Elveden, in Suffolk, he proceeded to Magdalene College, Cambridge, where he took the usual degrees. Appointed, in 1859, Assistant Colonial Secretary of Mauritius, he successively became Auditor General and Colonial Secretary of that island, relinquishing the last post in 1877 , on being appointed Colonial Secretary and Lieutenant Governor of Jamaica, whence he retired in 1883 , through ill-health. He was a member of the mission sent by the Government of Mauritius to congratulate the late King of Madagascar on his accession to the throne; and, being an ardent ornithologist, availed himself of the occasion by materially increasing (as he did during a subsequent visit made with that express purpose) the knowledge of the very peculiar fauna of that country, which he was almost the first English naturalist to investigate on the spot. In like manner he largely increased our knowledge of the zoology of the Mascarene Islands generally, and it is mainly due to his exertions that nearly complete skeletons of the marvellous "Solitaire" of Rodriguez were recovered from the caves of that island, as described in the Philosophical Transactions of the Royal Society. Sir Edward was one of the founders of the British Ornithologists' Union, a Fellow of the Linnean Society, and a Corresponding Member of the Zoological Society of London.

WE regret to see the announcements of the death of Dr. E. S. Bastin, professor of botany and materia medica at the Philadelphia College of Pharmacy, and of Mr. Louis P. Casella, the well-known scientific instrument maker.

THE southern portion of Bronx Park, which the Commissioners of the Sinking Fund of the City of New York have just allotted for the use of the New York Zoological Society, embraces an area of about 260 acres. The city authorities will annually provide the funds for the maintenance and care of the buildings, animals and collections in the Zoological Garden which will be established in the Park; but the grant for the first year is not to exceed sixty thousand dollars. The erection and original equipment of the buildings, and the animals to stock them, have to be paid for by the Zuological Society, which has to raise one hundred thousand dollars by subscription before this time next year, and the further sum of one hundred and fifty thousand dollars within three years of the commencement of the work of converting Bronx Park into a Zoological Garden. Strong efforts are therefore being made to secure to the Society the sympathy and support of a large number of members. An attractive report on the plans and purposes of the Society has been printed and circulated, and in it Mr. William T. Hornaday, the Director of the proposed Garden, describes the zoological gardens of Europe, and dwells upon the advantages offered by Bronx Park. He holds that none of the Gardens he visited "occupies ground which can for one moment be compared, either in physical character or in extent, with the matchless site that has been chosen by this Society for the Zoological Park of America." One of the conditions of the grant of South Bronx Park to the Society is that the Zoological Garden and its collections shall be open free to the public for not less than seven hours a day, or at least five days a week.

The Belgian Royal Academy announces prizes, mostly of the value of 600 francs, to be awarded in 1898 for essays on certain questions connected with the following subjects : In mathematical and physical science-on the critical phenomena, on theories of the constitution of solutions, on the correspondences (Verwandtschaften) between two spaces, and on the influence of the radical $\mathrm{NO}_{2}$ in certain compounds. In biological science-on the macroand micro-chemistry of digestion in carnivorous plants, on the physiology of some invertebrate animal, and on the organisation and development of the Platoda. A further prize of 1000 francs is offered, in memory of Jean-Servais Stas, for the best determination of the atomic weight of some element for which this constant is at present uncertain.

IN the last number of its Proceedings, the London Mathematical Society publishes the outlines of seven lectures on the Partitions of Numbers, which were delivered by the late Prof. Sylvester at King's College, London, during the year 1859 . The outline of each lecture was printed shortly before its delivery, and copies handed to those in attendance. The Professor's attention was shortly afterwards diverted to another branch of mathematics, with the result that his researches on compound partitions have hitherto remained unpublished; but shortly before his death, Prof. Sylvester yielded

No. I 435 , vOL. 55$]$ 